\title{
Media empowerment vs. strategies of control: Theorising news media and war in the $21^{\text {st }}$ Century
}

\section{Overview}

Conflict defined the $20^{\text {th }}$ century with the two world wars shaping the geo-political context for almost the entire century. The $21^{\text {st }}$ century has seen no let up, with two major US-led wars in Iraq and Afghanistan dominating the foreign policy agendas of Western governments and the militarised response, the so-called »war on terror «, to groups such as Al Qaeda. At the same time, the last 100 years have witnessed the rapid emergence of new forms of mass communication, including wireless radio, newsreels and cinema, mass circulation newspapers, television and the Internet. Right from the start, the power of communication in wartime was fully recognised: From the deployment of Nazi propaganda masterminded by Goebbels through to the creation of the Ministry of Information in Britain, tasked with the »maintenance of moral «, media became an integral part of national war efforts. Today, governments devote significant resources in order to shape the information environment in their favour and, in doing so, win a global battle for »hearts and minds«.

This article provides an overview and assessment of the ways in which political communication scholarship has sought to understand and explain the importance of news media vis-à-vis war and international politics. The aim is to review existing approaches that have shaped debates over the last 30 years and to critically evaluate the significance of major contemporary debates over new communication technology and organised persuasive communication (also frequently referred to as propaganda, perception management or strategic communication). Of course, news media are only one part of much broader communications media and analysis of mediums such as cinema and popular entertainment are of importance. But news media, including its contemporary online variants, remain the central site upon which information about war and conflict is disseminated. For this reason much of the relevant scholarship focuses on news media and this fact is reflected in the contents of this article. The article proceeds in three sections. The first section reviews the elite-driven orthodoxy that has traditionally informed our understanding of wartime media-state relations. The second assesses what is termed here as the first post-Cold War media empowerment debate, that of the CNN-effect debate in the 1990s. The third section assesses current debates over the new media environment, termed here as the second post-Cold War media empowerment debate and concurrent research on organized persuasive communication. The central objective is to assess both the extent to which the orthodox paradigm remains relevant to the 21 st century and the 
major questions now facing attempts to theorise the relationship between war and media. It is argued that existing theoretical accounts retain significant purchase, despite the emergence of the Internet-based contemporary media environment, and that greater academic attention needs to be paid to organised persuasive communication.

\section{The Elite-driven Orthodoxy: media in support of the state and war}

The orthodox view amongst political communication scholars has been that news media remain largely deferential of, and supportive toward, political elites during times of war and crisis. As discussed elsewhere ${ }^{1}$, the orthodox position is consistent with both realist and critical international relations scholarship which highlights the power of the state and presumes that domestic-level organisations such as the media, as well as publics, remain subservient to political and foreign policy elites. The early groundbreaking study by Daniel Hallin, The Uncensored War (1986), ${ }^{2}$ laid foundations for this orthodoxy. Focusing upon US media coverage of the Vietnam War, which resulted in the deaths of millions of people in South East Asia and divided US society, Hallin explored the widely held belief that US media coverage had adopted an oppositional stance toward US policy and, in doing so, contributed to the attrition of public and political support for the war. Indeed, the belief that a combination of rising US casualties, adversarial journalism and waning public support led to failure in Vietnam became known as the Vietnam Syndrome and, arguably, has dominated military and political mindsets ever since. However, Hallin's research found that US media coverage of the war was broadly supportive of it until 1968. During this phase US media operated within a »sphere of consensus « that had been defined by political agreement over the course of the war. In this period, coverage reflected well upon US forces with coverage being dominated by officially sourced stories about US soldiers and rarely showing images of any death and destruction. In 1968, however, communist forces launched the Tet Offensive which involved an uprising throughout South Vietnam. At this point, according to Hallin, critical reporting did start to emerge in mainstream US media, but this was only because elements within the Johnson administration itself had started to argue publicly over the course of the war: the scope of reporting had extended to embrace a »sphere of legitimate controversy « involving procedural criticism pertaining primarily to whether or not the US was winning the war in South East Asia and including more images of violence and suffering. Importantly, however, US media coverage never moved beyond this point into a »sphere of deviance " whereby more substantive criticism of the legitimacy of US action in Vietnam was made; the US was always presented as morally justified in fighting the war. Subsequent to Daniel Hallin's study, the empirical case for media deference in wartime has been repeatedly reaffirmed across a series of academic studies and in different national contexts. For example, the Glasgow University Media Group analysed and critiqued UK

1 Piers Robinson, »Political Communication in International relations and War « in: Political Communication, edited by Carsten Reinemann, Berlin, 2014.

2 Daniel Hallin, The Uncensored War: The Media and Vietnam, Berkeley, 1986. 
media coverage of the 1982 Falklands conflict, highlighting the willing complicity of broadcasters to provide »a nightly offering of interesting, positive and heart-warming stories of achievement and collaboration born out of a sense of national purpose « ${ }^{3}$. With respect to the Israeli context, Tamar Liebes details how hegemony has shaped and limited journalists covering conflict in the Middle East ${ }^{4}$ whilst, with respect to US media and the 1991 Gulf War, the widely-cited Taken by Storm, edited by Bennett and Paletz, provides extensive empirical confirmation of media deference to government. ${ }^{5}$

In terms of explaining this pattern of media deference, the most frequent explanation, and one that is invoked to explain both patterns of wartime and non-wartime media-state relations, relates to the close relationship between journalists and official sources: i.e. news media coverage ends up being supportive of government because journalists rely upon and defer to official sources. For example, Bennett's widely cited and paradigmatic indexing hypothesis highlights the »symbiotic « and »transactional « relationship between journalists and official sources which is generated by the need of officials to get their message across, and the need of journalists to produce news. For Hallin ${ }^{6}$ deference occurs because of a routine of objective journalism whereby objectivity is understood as reporting the range of existing viewpoints across the US legislature and executive. For Wolfsfeld, ${ }^{7}$ The Political Contest Model describes wartime media as an ideal-type example of media behaving as a faithful servant to the state whereby the conditions of privileged access and control of information create a power inbalance firmly in favour of military and political officials. He draws upon the 1982 Falklands to illustrate this point, showing how journalists travelling the 8000 miles to the war zone with the British Royal Navy were almost entirely reliant on British officials and military both for information and the capacity to communicate reports back to the UK.

Whilst reliance upon official sources is a convincing immediate factor that ties media reporting to official views, there are other explanations, specifically ideology, political economy and patriotism, which are rooted more deeply in underlying political and economic structures. Some of these are consistent with critical-theory approaches to world politics, some are consistent with realist theory. ${ }^{8}$ With respect to critical approaches, Hallin and Herman and Chomsky argue that, during the Cold War at least, ideological imperatives structured around anti-communism meant that US journalists and US policymakers shared the same worldview. ${ }^{9}$ As a result, events such as the Vietnam War could only ever be interpreted as a morally justified struggle against communism, and never as

3 Glasgow University Media Group (GUMG), War and Peace News, Milton Keynes, 1985.

4 Tamar Liebes, Reporting the Arab-Israeli Conflict: How Hegemony Works. London, 1997.

5 Lance W. Bennett and David L. Paletz (eds.), Taken by Storm: The Media, Public Opinion, and US Foreign Policy in the Gulf War. Chicago and London, 1994.

6 Hallin, The Uncensored War.

7 Gadi Wolfsfeld, The Media and Political Conflict: News from the Middle East, Cambridge and New York, 1997.

8 Robinson, »Political Communication in International Relations and War «, op. cit. (note 1).

9 Hallin, The Uncensored War; Edward Herman and Noam Chomsky, Manufacturing Consent: The Political Economy of the Mass Media, New York, 1986. 
a war of aggression against Vietnamese people. Herman and Chomsky, ${ }^{10}$ in their propaganda model, are more explicit than Hallin in terms of discussing the political economy of the US news media, and the consequences of this for media coverage. For them, the size, concentration of ownership and profit orientation of mainstream US media interlink with political elites: the end result is that media reporting tends largely to support both political and economic elites. A number of scholars identify patriotism, or national identity, as the key factor in shaping media reporting of war. ${ }^{11}$ For example, some of the elitedriven accounts emphasise how appeal to patriotism is a powerful rhetorical tool employed by policy makers in order to silence dissent. At the same time, as Muller's rally round the flag thesis describes, ${ }^{12}$ populations tend to instinctively support their leadership at times of national crisis; and, as Bennett and Paletz argue, commercial news media are vulnerable to the concern that patriotic publics will not welcome critical coverage during war. ${ }^{13}$ In addition, the patriotic sentiments of journalists themselves might naturally incline them to support »their « side during a war. ${ }^{14}$ These arguments rooted in patriotism dovetail with realist international relations theory, which assumes the pre-eminent importance of national identity and loyalty to the state amongst publics, a phenomenon that is also understood as »natural « and $»$ right $\ll .{ }^{15}$

The elite-driven orthodoxy is not without its shortcomings. Specifically, and as can be seen in the preceding discussion over explaining these patterns, it is not clear which factors hold the greatest sway in terms of shaping supportive media coverage. On the one hand, media deference might be explained through some variant of the indexing bypothesis. ${ }^{16}$ On the other hand, broader ideological structures such as anti-communism or patriotism that are exogenous to the journalist-official relationship could conceivably be shaping the views of both journalists and policy-makers. ${ }^{17} \mathrm{It}$ is also possible that all these factors combine in order to create a pattern of media reporting that is deferential to government officials. Overall, it is unclear as to the appropriate explanatory weighting that should be accorded the factors theorised to shape coverage.

Another area of debate concerns the empirical accuracy of those studies that have measured media deference to government. For example, in his 2003 Political Communication article Scott Althaus argues that scholars have under-measured press criticism by ignoring critical contributions raised by journalists, failing to distinguish adequately between procedural and substantive types of criticism, and relying upon proxy data rather

10 Ibd.

11 GUMG, War and Peace News, op. cit. (note 3); Bennet and Paletz Taken by Storm, op.cit. (note 5); Liebes, Reporting the Arab-Israeli Conflict, op. cit. (note 4).

12 John Mueller, War, Presidents and Public Opinion, New York, 1973.

13 Bennett and Paletz, Taken by Storm, op.cit. (note 5), 284.

14 Liebes, Reporting the Arab-Israeli Conflict, op. cit. (note 4).

15 Robinson, »Political Communication in International Relations and War«, op. cit. (note 1).

16 Lance W. Bennett, »Toward a Theory of Press-State Relations in the United States « in: Journal of Communication, 40 (2), pp.103-27.

17 Zaller, John and David Chiu, »Government's little helper: US press coverage of foreign policy crises, 1945-1999« (http://www.sscnet.ucla.edu/polisci/faculty/zaller/Gov's\%20Little\%20H elper/GovHelper.PDF), p. 10. Downloaded 2 September 2014. 
than analysing actual news content. ${ }^{18}$ Part of the problem here is that measuring news bias is a complex, time-consuming and challenging task, with multiple possibilities for researchers to miss analytically significant dimensions of news coverage. ${ }^{19}$ As a result, there is still potential for some debate as to how far news media actually are deferential during times of war and crisis. It is also the case that the elite-driven models do not theorise exceptions to the rule where processes of elite domination break down. These points notwithstanding, it is still the case that the majority of empirical scholarship on media and war supports the elite-driven model whilst actual challenges suggest modifications to, rather than a complete over-turning of, the elite driven paradigm. ${ }^{20}$ More generally, over the last 20 years, questions have emerged surrounding the ending of the Cold War and changes to the media environment which have suggested, at least to some, a more pluralised relationship between media and the state. And it is to these that we now turn.

\section{The first post-Cold War media-empowerment debate: The CNN effect}

The final fifteen years of the $20^{\text {th }}$ century brought with it dramatic shifts both in the geopolitical landscape and the emergence of new communication technology. It also ushered in what was for some a new form of warfare that involved fighting humanitarian wars on behalf of oppressed and suffering people. Specifically, some scholars argue that two factors conjoined in order to enable the emergence of a more pluralist relationship between media and state. The first concerned the passing of the Cold War bi-polar standoff which had created an ideological bond (the ideology of anti-communism discussed in the previous section) between policy-makers and journalists; freed from the strictures of this bond, journalist were more able to challenge and criticise foreign policy makers. The second factor related to the apparently pluralising consequences of developments in communication technology. The arrival of 24-hour rolling news coverage (e.g. CNN) and the associated genre of global media, coupled with portable editing and satellite communication equipment enabled real-time reporting direct from conflict zones and provided journalists with the ability to bypass official sources, thereby potentially confounding the continued significance of the indexing hypothesis discussed earlier. ${ }^{21}$ At the heart of what became known as the CNN-effect debate was an apparently new-found media power driving armed interventions during humanitarian crises in war-torn countries such as Somalia (1992-93), Bosnia (1992-1995) and Kosovo (1999). For many

18 Scott L. Althaus, »When news norms collide, follow the lead: New evidence for press independence « in: Political Communication, 20(3): pp. 381-414. 2003. See also Kevin Coe »George W. Bush, Television News and Rationales for the Iraq War in: Journal of Broadcasting and Electronic Media, 55(2011/3): pp. 307-324.

19 For an overview see David N. Hopmann, Peter van Aelst and Guido Legnante, »Political balance in the news: A review of concepts, operationalizations and key findings «, in: Journalism, 13(2012/2), pp. 240-257.

20 Ibid.

21 Bennett, »Toward a theory of press-state relations«, op. cit. (note 16).

ZfP 61. Jg. 4/2014 
scholars, ${ }^{22}$ these interventions were driven by emotive media coverage of suffering people that, in turn, created a political imperative for Western governments to intervene. Notably, these developments were understood as evidence for the liberal interventionist and humanitarian vision of international politics, a world in which, via so-called humanitarian intervention, the international community was able and willing to act in the interests of protecting basic human rights. ${ }^{23}$ To the extent that some perceived humanitarian intervention to be a new form of international action, these instances of influence appeared to be substantive. Also, the idea that it was media coverage driving policy decisions to intervene appeared consistent with the interest liberal IR theorists had in the role of nonstate actors. In short, foreign policy now appeared to be more than simply the outcome of state-centered power politics that realist theory suggested. ${ }^{24}$

In fact, the more radical claims regarding the CNN effect were quickly brought into doubt. Starting with journalist Nik Gowing's Harvard study, ${ }^{25}$ the argument was put forward that media influence on policy was largely cosmetic, occasionally tactical (i.e. procedural level) but only rarely strategic (i.e. substantive level). So, according to Gowing, media coverage of suffering people often triggered cosmetic policy responses, such as the high-profile airlifting of a few injured children out of a war zone, or tactical responses whereby limited air strikes might be used in response to an atrocity. Coverage rarely, however, impacted upon strategic decisions to actually intervene, or indeed withdraw, from a particular country. For other scholars, the CNN effect was understood as conditional: Robinson argued that media impact was more likely when political elites were divided and unsure of policy (the condition of policy uncertainty) ${ }^{26}$ whilst Livingston concluded that, although media might have a significant influence upon relatively low-cost responses to humanitarian crises, such as food aid delivery and diplomatic responses, politically and economically high-cost operations such as armed intervention were more likely to be driven by factors other than media pressure. ${ }^{27}$ Finally, and drawing in part from detailed case study analysis of the 1999 NATO air war against Serbia, both

22 For example see Martin Shaw, Civil Society and Media in Global Crises. London, 1996.

23 Robinson, »Political Communication in International Relations and War«, op. cit. (note 1).

24 Ibid.

25 Nik Gowing »Real time television coverage of armed conflicts and diplomatic crises: Does it pressure or distort foreign policy decisions «, The Joan Shorenstein Center on the Press, Politics and Public Policy at Harvard University, Working Paper Series, 1994.

26 Piers Robinson, The CNN Effect: the myth of news foreign policy and intervention, London and New York, 2002.

27 Steven Livingston, »Clarifying the CNN effect: an examination of media effects according to type of military intervention «, research paper R-18, June, Cambridge, MA: The Joan Shorenstein Barone Center on the Press, Politics and Public Policy at Harvard University. 1997. 
Babak $^{28}$ and Robinson ${ }^{29}$ argued that media was able to, amongst other factors, influence decisions to use air power but not ground troops in response to a humanitarian crisis. ${ }^{30}$

In short, the more radical claims regarding the $\mathrm{CNN}$ effect, which suggested a dramatically pluralised relationship between governments and media in which foreign policy was being driven by media pressure, gave way to moderate claims and a more sober analysis of the extent of media influence. At the very least, however, the CNN-effect debate was successful in highlighting the possibility that the media-state relationship was not always one of straightforward subservience. Reflecting this direction of thinking have been a series of attempts to theorise a more nuanced and two-way understanding of the influence between media and state, both in conditions of war and foreign policy more generally. For example, Gadi Wolfsfeld's political context model purports to show that, when non-elite groups were able to initiate events, control the information environment and gain the support of at least parts of a political elite, they can be successful at influencing media, generating substantive-level media criticism and substantive-level influence. ${ }^{31}$ By way of example, he analyses the Palestinian Intifada in 1987 when Palestinians were able to initiate the uprising, limit the control that Israel had over the movement of journalists in the occupied territories and mobilise elite support from the Israeli political left. As a result, and in the context of an armed uprising against Israel, media coverage was framed in a way that effectively promoted the cause of the Palestinians. Analysing British news media coverage of the 2003 invasion of Iraq, Robinson et al. through a comparative analysis of four British television news channels and seven national newspapers, find that a minority of media outlets demonstrated a significant level of independence from the UK government, even to the extent of taking a public stand against the invasion. ${ }^{32}$ Although there were limits to this independence, Robinson et al. argue that the system characteristics of the UK media, which include a large number of national newspapers operating in a highly competitive market, coupled with relatively high levels of journalistic professionalism within some media outlets, meant that a minority of UK media presented a more serious challenge to the UK government than predicted by the elite-driven model. ${ }^{33}$

Other neo-pluralist accounts are slightly more circumspect regarding the degree of power that media, and non-elite groups, might be able to obtain. For example, both

28 Babak Bahador, The CNN effect in action: How the news media pushed the West toward war in Kosovo. New York. 2007.

29 Robinson, The CNN effect, op. cit (note 26).

30 For recent debate over the CNN effect see Piers Robinson, »The CNN Effect Revisited: mapping a research agenda for the future in The CNN Effect Revisited, Special Issue edited by Piers Robinson, Media, War and Conflict; 2011, 4(1): pp. 3-11.

31 Wolfsfeld, The Media and Political Conflict, op. cit. (note 7).

32 Piers Robinson, Peter Goddard, Katy Parry, Craig Murray and Philip M. Taylor, Pockets of Resistance: British news media, war and theory in the 2003 invasion of Iraq, Manchester and New York, 2010.

33 See Althaus, »When news norms collide«, op. cit. (note 18); Coe »George W. Bush, Television News and Rationales for the Iraq War", op. cit. (note 18), and Piers Robinson, Peter Goddard, Kay Parry and Craig Murray, »Testing models of media performance in wartime: U.K. TV news and the 2003 invasion of Iraq in: Journal of Communication, 59(2009/3), pp. 534-63.

ZfP 61. Jg. 4/2014 
Entman's cascading activation mode ${ }^{34}$ and Robinson's policy-media interaction model $l^{35}$ emphasise the interaction between elite-dissensus and rising levels of media independence. For Entman, more critical media reporting can occur when a) dissensus exists among officials at the top level of government, b) mid-level officials promote challenges to existing policy, and c) events occur that are culturally ambiguous and open to contestation. For Robinson, critical media reporting is triggered when policy-makers are uncertain over policy and/or publicly arguing over policy. In these circumstances media reports that are critical of policy can provide influential ammunition for those policy makers, and sometimes other actors, seeking a change in policy. Most recently, Baum and Groeling, in their analysis of media, public opinion and US foreign policy, argue that, in circumstances of protracted war, the combination of rising US casualties and the propensity of news media to consider elite criticism of government policy as more newsworthy than elite support, means that media pose an increasing challenge to the US government. ${ }^{36}$ The important feature of these three accounts is that media independence is relatively limited because elite dissent and debate is theorised as being such an important part of generating critical media coverage. As such, media power is not seen as, to any great degree, enabling non-elite influence upon media and policy; but rather as becoming an important actor in the context of elite debates over policy. As such, influence under these models is more likely to be at a more procedural level as opposed to substantive level.

Whether suggestive of the possibility of substantive non-elite influence over media or a media that becomes a key player in times of elite dissensus, these neo-pluralist accounts, to an extent, dovetail with liberal international relations arguments about the importance of non-state actors, emphasising the significance of domestic-level variables and providing theoretically-grounded evidence that foreign policy and world politics are not only the outcome of self-interested and militarised power politics. ${ }^{37}$ These accounts are also important because, albeit to varying degrees, none of them seek to overturn fully the elite-driven orthodoxy. Indeed, each of the accounts provides significant theoretical and empirical support for the claim that, on balance, governments and political elites possess considerable power over media when it comes to international politics. As such, what results from these accounts is a constructive and, ultimately, well-grounded research agenda, in both theoretical and empirical terms, and that seeks to deepen our understanding of the multiple relations between political elites, non-elites and media.

34 Robert Entman, Projections of Power: framing news, public opinion and US foreign policy. Chicago, 2004.

35 Piers Robinson, »The policy-media interaction model: measuring media power during humanitarian crisis « in: Journal of Peace Research, 37 (2000/5), pp: 613-633.

36 Matthew Baum and Tim Groeling, War Stories: the causes and consequences of War, Princeton, 2010.

37 Robinson, »Political Communication in International Relations and War«, op. cit. (note 1.). 


\section{The second post-Cold War media empowerment debate: internet-based communication technology}

To the extent that political communication scholarship has made progress in terms of developing nuanced and sophisticated accounts of the dynamics between media and state, the last ten years have witnessed an Internet-driven revolution that has, in some ways, transformed the media environment. For some, as we shall see, this means that there has been a dramatic pluralisation, even diffusion, of power such that existing theoretical frameworks no longer hold purchase. At the same time, states and other powerful actors have also updated and expanded their approaches to so-called media management (historically described as propaganda). In the following pages these arguments are critically evaluated and the continued relevance of existing paradigms is assessed.

\subsection{Internet, global media and the media-empowerment thesis}

For many, the proliferation of new communication technology such as the emergence of digital cameras contained within mobile phones and the Internet appears to create a degree of transparency to events around the world that is unprecedented. ${ }^{38}$ Potentially, any event can be captured on »camera « and that information then passed around the world instantaneously via the Internet or global media. In addition, the rise of non-Western global media such as Arab-based network Al-Jazeera, as well as the Internet, means that such images (and their story) can be communicated to global audiences. Many now argue that these developments have a radical impact in terms of bringing information and news to people more quickly and, in turn, creating greater difficulty for governments in influencing (or manipulating) news agendas. For some, this can be described as the pluralisation of power; for others it is symptomatic of the chaos and complexity generated by the new media »ecology « and suggests a profoundly diffused communications environment the dynamics of which cannot be captured by existing theoretical paradigms, neither orthodox nor neo-pluralist. The recent and ongoing controversy over both Wikileaks, which has disseminated large quantities of secret US government documents regarding the wars in Iraq and Afghanistan, and Edward Snowden's revelations regarding the NSA and US spying, epitomise the apparently limited capacity governments have to control information flows in the Internet era. Most recently, during the so-called »Arab Spring«, social media have been implicated in the ability of people to organise and rise up against authoritarian governments throughout the Middle East; ${ }^{39}$ also the dramatic advances of

38 Manuel Castells, Communication Power, Oxford, 2009; Nik Gowing, »Time to Move on: New media realities-new vulnerabilities of Power « in Special Issue The CNN effect reconsidered, edited by Piers Robinson, Media, War and Conflict 4 (2011/1): pp. 13-19; Andrew Hoskins and Ben O'Loughlin, War and Media: the emergence of diffuse war, Cambridge, 2010.

39 See for example Zeynap Tufekci and Christopher Wilson, »Social Media and the Decision to Participate in Political Protest: Observations From Tahrir Square in: Journal of Communication, 62 (2011/2), pp. 363-379, and Gowing, «Time to move on«, op. cit. (note 38). 
Islamic State throughout Iraq and Syria appears to be enabled, in part, via their adept communication of fear via social media.

Liberal interventionists and those within humanitarian circles have also been quick to speculate over the empowering potential of new communication technology. For example, some argue that Internet-based technology and digital communication can provide people within conflict zones with a practical ability to report on, and highlight, humanitarian situations by rapidly communicating information to external humanitarian actors and "global media. ${ }^{40}$ Others have pointed to the utility of social media platforms and other ICTs (information communication technologies) in terms of providing information that can facilitate early warnings and also co-ordinate more effective responses ${ }^{41}$. Indeed, such technology may have the potential to empower actors at the local level, thus furthering the hybrid nature of interactions between local actors and intervening actors. ${ }^{42}$ Beyond facilitating bottom-up or grassroots action, others have emphasised the ability of new media technologies to improve the capability of NGOs to advocate and influence policy at the global level. Here, the proliferation of digital communication technology facilitates the emergence of transnational advocacy networks, enabling the communication and mobilisation of action at national and international levels. ${ }^{43}$ Finally, although sometimes guarded, optimism has also been expressed about the ability of the contemporary global media environment, through its representation of crisis and suffering, to strengthen »wider, globalizing, discourses of human rights and struggles for citizenship and democracy ${ }^{44}$. Here, claims continue to be advanced, tentatively, that global media such as Al Jazeera, BBC World and CNN have the potential to develop cosmopolitan values and associated feelings of solidarity at a global level.

In sum, these developments suggest that, at least, the pluralist claims and neo-pluralist models have greater validity in today's so-called $»$ media ecology $\ll{ }^{45}$ At most, they indicate a transformation in the relations of power described by existing approaches, both orthodox and neo-pluralist, such that these are no longer useful in the $21^{\text {st }}$ century due to the diffuse, chaotic and complex media environment. These developments have been drawn upon by some liberal and post-structuralist international relations scholars in order to emphasise the contingency, variability and uncertainty surrounding the contem-

40 Stuart Allan, Citizen Witnessing: revisioning journalism in times of crisis, Cambridge, 2013.

41 See for example E. Asimakopoula and N. Bessis (eds), Advanced ICTs for Disaster Management and Threat Detection: Collaborative and Distributed Frameworks (IGI Global), 2010; P. Meier and J. Leaning, Applying technology to Crisis Mapping and early warning in Humanitarian Settings, Working Paper Series, Harvard Humanitarian Initiative. 2009.

42 Roger MacGinty, »Hybrid Peace: The interaction between top-down and bottom-up peace Security Dialogue, 41(4): 391-412. 2010.

43 Steven Livingston and K. Klinkworth, K. »Narrative Power Shifts: Exploring the Role of ICTs and Informational Politics in Transnational Advocacy « in: The International Journal of Technology, Knowledge, and Society 6 (2010/5): pp. 43-64.

44 Simon Cottle, »Taking Global Crises in the News Seriously: Notes from the dark side of globalization « in: Global Media and Communication, 7(2011/2): pp. 77-95, p. 88.

45 Simon Cottle, Mediatized Conflict: Developments in Media and Conflict Studies: Maidenhead, 2006. 
porary media-foreign policy nexus. ${ }^{46}$ But to what extent can such claims be substantiated? On the one hand, it is certainly the case that communication technologies such as the Internet, as well as the omnipresence of digital cameras and mobile phones, means that there is more information circling the global media sphere and that traditional patterns of indexing, ${ }^{47}$ whereby journalists are heavily dependent upon official sources, may seem to be a thing of the past. Moreover, there is now unprecedented potential for individuals to readily seek out alternative sources of information that present radically different viewpoints from those presented by mainstream media and political elites. However, there are four reasons why the more radical claims should be treated with caution.

\subsection{The persistence of established news media}

Even if the contemporary media environment enables people to seek out alternative information sources, it remains the case that most people continue to use traditional news media as their most trusted and significant source of information. For example, and with respect to the US context, although there exists a long-term decline in viewing figures for the traditional network evening news (ABC, CBS and NBC), with a loss of around $50 \%$ of their audience since 1980 , these remain extremely popular with the major outlets attracting over seven times as many viewers as the three major cable news channels (CNN, Fox News and MSNBC). ${ }^{48}$ Regarding the major newspapers, by far the largest slice of newspaper circulation is taken by traditional titles with the Wall Street Journal, USA Today and New York Times in 2013 receiving between them around 7 million readers as set against the half million readers of the next largest newspaper. ${ }^{49} \mathrm{~A}$ similar pattern can be seen internationally: drawing upon the World Value Survey (www.worldvaluesurvey.org) of 57 countries, Wolling and Emmer note that the news provided by traditional electronic media - TV and radio - can be regard as the backbone of basic political information in most parts of the world. ${ }^{50}$ In short, the major traditional news media brands have not been unseated as the major providers of news and, importantly, they all maintain a strong online presence. Another popular argument regarding the Internet environment concerns the use of platforms such as Twitter and Facebook and the way in which they appear to have become important disseminators of news. However, the $2012 \mathrm{Pew} »$ State of the Media«study showed that »social networks at this point are

46 Hoskins and O'Loughlin, War and Media: the emergence of diffuse war, op. cit. (note 38); Leni Hansen, »Theorising the image for Security Studies: Visual securitization and the Muhammed Cartoon Crisis « in: European Journal of International Relations 17(2011/1): pp. 51-74.

47 W. Lance Bennett, News: The politics of illusion, $9^{\text {th }}$ ed. New York, 2011.

48 Source http://www.journalism.org/2014/03/26/state-of-the-news-media-2014-key-indicator s-in-media-and-news/ Download date 12 September 2014.

49 Source The Pew Research Center's Project for Excellence in Journalism »The State of the News Media 2014 «(http://www.journalism.org/media-indicators/average-circulation-at-the-top-5u-s-newspapers-reporting-monday-friday-averages/ Download date 12 September 2014).

50 Jens Wolling and Martin Emmer, »Individual political communication and participation « In: Carsten Reinemann (ed.), Handbook of Communication Science: Political Communication, Berlin, 2014, pp. 449-468, p. 456.

ZfP 61. Jg. 4/2014 
mostly an additional way to get the news, rather than a replacement source $\ll$ : Moreover, the emerging dominance of the smartphone merely adds to "people's news consumption, strengthening the lure of traditional news brands «. ${ }^{11}$ As such, platforms such as Twitter and Facebook merely echo the established media, or otherwise simply lead users to established media sites. In short, arguments regarding the pluralisation of news media outlets and information sources make less sense given the persistence of traditional news media.

\subsection{The persistence of official sources}

While comparative studies that evaluate the use of sources across pre-Internet and Internet periods are hard to come by, there is no clear evidence that journalists' dependence upon official sources has actually been substantially altered. One of the most significant studies to date, by Steven Livingston and Lance Bennett, ${ }^{52}$ explored the question of whether there has been a rise in so-called event-driven newes ${ }^{53}$, whereby reporters were covering events live and in ways that undermined familiar patterns of institutionallydriven news in which officials were largely in control of the news agenda. Examining 1200 news segments from CNN across the period 1994-2001, they found that, whilst event-driven news had increased, »officials seem to be as much a part of the news as ever ${ }^{54}$. In short, whilst technology was bringing more event-driven news from around the world, journalists were still relying upon officials to interpret these events. Outside the US context, detailed analysis of British media coverage of the 2003 Iraq war, which occurred in the context of a well-established Internet environment, also revealed heavy reliance upon official sources. Specifically, Pockets of Resistance ${ }^{55}$ showed that coalition actors were by far the most represented news source across a wide range of media outlets, even those outlets that had adopted an anti-war stance: across television news $56 \%$ of quotes were attributable to coalition sources and no other actor received more than $10 \%$, whilst a similar pattern in print media was revealed with $45 \%$ of quotes from coalition sources and no other actor achieving more than $10 \%$ of quotes. The conclusion of this study was that media coverage of this war was narrated largely through the voice of British and American military and government spokespersons.

51 Source The Pew Research Center's Project for Excellence in Journalism, »The State of the News Media 2012: an annual report on American Journalism «, http://stateofthemedia.org/files/201 2/08/2012_sotm_annual_report.pdf. Download date 18 February 2013.

52 Steven Livingston and Lance W. Bennett, »Gatekeeping, indexing and live-event news: is technology altering the construction of news? in Political Communication, 20(2003/4), pp. 363-80.

53 Regina Lawrence, The Politics of Force: media and the construction of police brutality, Berkeley, 2000.

54 Livingston and Bennett, »Gatekeeping, indexing and live-event news«, op cit. (note 52), p. 376.

55 Robinson et al, Pockets of Resistance, op. cit. (note 32). 


\subsection{The persistence of ideological constraints}

Even if the Cold War is a thing of the past, it remains the case that ideological imperatives shape media discourses. With respect to the »war on terror «, for example, David Domke's analysis of the Bush administration, the "war on terror « and the US press provides empirical evidence in support of the emergence of binary discourses opposing good and evil and security and peril. ${ }^{56}$ These, in turn, were underpinned both by a sense of mission and a universal obligation to spread freedom. Similarly, Andrew Rojecki analysed how the Bush administration following 9/11 employed an ideologically-driven discourse that projected an image of the United States »as endowed with unique institutional and moral qualities ${ }^{57}$ so as to mobilise elite media support in favour of unilateral military action. Beyond the operation of the »war on terror « as an ideological constraint, or at least as a prevalent political narrative, other influential discourses are humanitarian warfare ideology and nationalism itself. Examining the ways in which British media presented the invasion of Iraq as part of a humanitarian endeavor, akin to the humanitarian interventions of the 1990s in countries such as Somalia (1992-93) and Bosnia (1995), Pockets of Resistance shows that the bulk of UK media coverage bought into a "humanitarian warfare narrative « during the 2003 invasion of Iraq. In essence, a discourse that had emerged during the 1990s surrounding the legitimacy of humanitarian intervention became a powerful way of structuring debate over the invasion of Iraq, an invasion that had dubious »humanitarian « credentials. ${ }^{58}$ With respect to nationalism, for all the rhetoric and analysis regarding the decline of nationalism due to globalisation ${ }^{59}$, a number of substantial studies conducted over the last ten years support the continued importance of nationalism as a constraining ideology which limits the ability of media to be critical and independent of their respective governments. For example, Kolmer and Semetko's study of US, British, Czech, German and South African news coverage of the Iraq War found that coverage was consistently »conditioned by the national contexts in which it was produced $\aleph^{60}$; Goddard et al. ${ }^{61}$ in their study of the British press and the Iraq war, found

56 David Domke, God Willing? Political Fundamentalism in the White House, the War on Terror and the Echoing Press, London, 2004.

57 Andrew Rojecki, »Rhetorical Alchemy: American Exceptionalism and the War on Terror « in: Political Communication 25 (2004): pp. 67-88, p. 67.

58 Robinson et al, Pockets of Resistance, op. cit. (note 32), pp: 102-105. On the eve of the Iraq invasion, The British Attorney General advised the British Prime Minister that »I know of no reason why it [humanitarian intervention] would be an appropriate basis for action in the present circumstances «; Baron P. Goldsmith (2003), »Iraq: Resolution 1441 « (Legal advice to the Prime Minister prior to the invasion of Iraq, 7 March): http://news.bbc.co.uk/1/shared/b sp/hi/pdfs/28_04_05_attorney_general.pdf (accessed 2 March 2013).

59 Howard Tumber and Frank Webster, Journalists Under Fire: Information War and Journalistic Practices, London, 2006, p.163.

60 C. Kolmer and Holli Semetko, »Framing the Iraq War: Perspectives from American, U.K., Czech, German, South African, and Al-Jazeera news" in: American Behavioural Scientist, 52(2009/5), pp. 643-56, p. 654.

61 Peter Goddard, Piers Robinson and Katy Parry, Patriotism meets plurality: reporting the 2003 Iraq War in the British Press « in: Media, War and Conflict 1(2008/1): pp. 1-9.

ZfP 61. Jg. 4/2014 
that even the anti-war press in Britain felt obliged to patriotically support British soldiers. It is important to note that much of this research indicates that nationalism shapes coverage, not in an overtly jingoistic fashion, but rather in the sense of Billig's notion of »banal nationalism«. He notes:

»Nationhood provides a continual background for their political discourses for cultural products, and even for the structuring of newspapers. In so many little ways, the citizenry are daily reminded of their national place in a world of nations. However, this reminding is so familiar, so continual, that it is not consciously registered as reminding. $\ll^{62}$

Ideological imperatives therefore remain powerful: the ideology of the Cold War has passed, but political imperatives such as the » war on terror «, »humanitarian warfare « and nationalism continue to exert an effect on media output.

What is common to all these ideological imperatives is that they can be treated as exogenous to the media environment, whether that is Internet-based communications media or traditional off-line news media. Their existence, in other words, is not determined, at least in the first instance, by communication media. Moreover, what is common to all these ideological constraints, whether anti-communism, the »war on terror «, »humanitarian warfare« or nationalism, is the way in which they help to locate "us « as either righteous victims or saviors of the oppressed. Whether by producing simplifying dichotomies between »us « and »communists « or between »us « and »terrorists «, the principle objective of locating »us « as morally superior and on the side of justice is achieved. In that way, difficult questions surrounding »our « own behaviour and the possibility that our own motives are less than pure simply fail to be asked. Through these ideological filters the world, quite simply, is described in terms of "goodies and baddies«,»white hats and black hats«. ${ }^{63}$

\section{Contemporary approaches to influence and control}

The discussion of ideology brings us back to the question of power and how it might be exercised in the contemporary media environment. An under-theorised component of media-state dynamics concerns the institutions and strategies that work to shape the information environment. Put simply, powerful actors expend a considerable amount of time and effort in order to influence opinions and behaviour. Historically, activities involving organised persuasive communication have been labeled as propaganda. Today, a euphemism industry abounds and a variety of terms are used in order to describe activities aimed at influencing opinions and organising conduct including public relations, public diplomacy, political marketing, organised persuasion, corporate communications, organ-

62 Michael Billig, Banal Nationalism, London, 1995: p. 8.

63 John Mearsheimer, »Hans Morgenthau and the Iraq War: realism versus neo-conservatism « in: Open Democracy. 2005, Available on line at http://www.opendemocracy.net/democracy-am ericanpower/morgenthau_2522.jsp. Download date 27 February 2013. 
ised political persuasion, strategic communications, perception management, psychological operations (psy ops), psychological warfare, information operations and public affairs.

Of course, organised persuasive communication has always been seen by many in military and political circles as vital to winning wars. But recent history highlights the extent to which such activities have become ever more entrenched. It was during the Falklands conflict in 1982 that the British government demonstrated the utility of placing journalists alongside combatants as a means to foster sympathetic reporting. Learning in part from the British experience, the US military adopted the pool system in the $1991 \mathrm{Gulf}$ War, allowing selected journalists to accompany frontline units while others were channeled towards memorable set-piece press briefings. It was largely the use of dramatic images of »smart « bombs and sanitised language (such as the use of the terms »collateral damage « and »surgical strikes «) during these briefings that ensured that media coverage did not relay too much of the grim reality of war. Since the 1999 Kosovo conflict, attempts to manage the information environment during wars and crises have been strengthened. Coalition military operations in Kosovo, Afghanistan and the 2003 Iraq War have been accompanied by sustained and highly organised attempts to influence media agendas by promoting coverage of some issues rather than others and by encouraging the framing of stories in ways that support the government's cause. At least some of the impetus for these attempts during the 2001 war in Afghanistan came from the UK government's Director of Communications and Strategy, Alastair Campbell, whose:

»[...] solution was to create Coalition Information Centres (CICs) in Washington, London and Islamabad that would coordinate the release of information, attempt to control the news agenda and rebut opposition claims in exactly the way that the Clinton- Blair $>$ war room $<$ model operated in domestic politics. $« 64$

Other activities inherent in the »war room « model include the coordinated use of press releases, news media appearances, press conferences and speeches. In strategic terms, these activities seek to encourage the development of common news media frames over time. In tactical terms, they serve to minimise coverage of damaging or hostile stories and to discredit oppositional counter-narratives. A recent example of the influence and effectiveness of organised persuasive communication can be seen during the run-up to the 2003 invasion of Iraq. In the US, the White House Information Group was set up in August 2002 to co-ordinate a »systematic media campaign $\aleph^{65}$ that would persuade the American public of the threat posed by Iraq's alleged WMD activities. By September 2002, administration officials were publicly discussing the possibility of a nuclear attack from Iraq with the chilling soundbite » We don't want the smoking gun to be a mushroom cloud « used by Secretary of State Condoleeza Rice on CNN. ${ }^{66}$ In the UK context, and

64 Robin Brown, »Spinning the War: political communications, information operations and public diplomacy in the War on Terrorism «, in: Daya Thussu and Desmond Freedman (eds.), War and the Media: Reporting Conflict 24 (2003/7), pp. 87-100, p. 93.

65 Lance W. Bennett, Regina Lawrence and Steven Livingston. When the Press Fails: from Iraq to Hurricane Katrina. Chicago, 2007, p. 18.

66 Ibid., pp. 22-23.

ZfP 61. Jg. 4/2014 
at the same time as the perception management campaign got underway in the US, a dossier based on intelligence about Iraq was published in September 2002, written by the Joint Intelligence Committee but with substantial involvement from the Prime Minister's office and from Alistair Campbell (Blair's Communications Director). In what has become a controversial and discredited process, ${ }^{67}$ the dossier created an exaggerated sense of the threat from Iraq, suggesting in particular that Iraq could fire strategic weapons of mass destruction within 45 minutes of an order to do so, none of which could be sustained by the available intelligence. The dossier was, to all intent and purpose, an act of deception. ${ }^{6}$ The news media reported its publication giving particular attention to the claim that Iraqi WMD could be ready »within 45 minutes of an order to use them « (Prime Ministers Office, 2002); »Brits 45 minutes from doom « was one newspaper's headline. Currently, and against the backdrop of failing military engagements in Iraq and Afghanistan, interest in the concept of strategic narratives as a way of shaping and influencing people has become common. ${ }^{69}$ Recently attention has been paid to the realisation of successful organised persuasive communication with respect to "public diplomacy « in the context of the Internet-based contemporary information environment. ${ }^{70}$

The extent and penetration of organised persuasive communication is poorly understood by academics. Indeed, the principle theoretical accounts outlined earlier in this article rarely go beyond identifying the propensity of journalists to defer to official sources when shaping news agendas and frames. Little attempt is made to consider the extent to which the information being passed on by officials has already been through a process of manipulation and modification which is highly organised, directed, and which frequently, although not always, involves forms of deception, including lying, distortion and omission. ${ }^{71}$ Indeed, the deceptive and coercive dimensions of these campaigns are also not well understood by political communication researchers ${ }^{72}$. Perhaps most worryingly, recent figures from the Pew Research Centre show that, following years of cut backs at the major media organisations, so-called "public relations « (PR) experts, i.e.

67 Eric Herring and Piers Robinson, »Report X marks the spot: The British government's deceptive dossier on Iraq and WMD « in: Political Science Quarterly, forthcoming; Eric Herring and Piers Robinson, »Deception and Britain's Road to War in Iraq « in: International Journal of Contemporary Iraqi Studies 8 (2014/2); Alan Doig and Mark Pythian, »The National Interest and the Politics of Threat Exaggeration: The Blair Government's Case for War Against Iraq « in: The Political Quarterly 76 (2005/3): pp. 68-76; John N. L. Morrison,»British Intelligence Failures in Iraq in: Intelligence and National Security 26 (2011/4), pp. 508-520.

68 Herring and Robinson, »Report X marks the spot «, op. cit. (note 67).

69 See, for example, NATO's virtual community of strategic communication at http://www.aco .nato.int/stratcom.aspx, downloaded 2 September 2014.

70 Craig Hayden, »Logics of Narrative and Networks in US Public Diplomacy: Communication Power and US Strategic Engagement « in: Journal of International Communication, 2013; J. Pamment, New Public Diplomacy in the 21st Century: A Comparative Study of Policy and Practice, Routledge, 2012; R.S. Zaharna, Battles to bridges: U.S. strategic communication and public diplomacy after $9 / 11$, London, 2009.

71 Herring and Robinson, »Report X Marks the Spot«, op. cit. (note 67).

72 John Corner, »Mediated politics, promotional culture and the idea of propaganda «, in: Media, Culture E Society 29 (2007/4), pp. 669-677; Christopher Simpson, Science of Coercion: communication research and psychological warfare 1945-1960, Oxford, 1996. 
those professionals tasked with organised persuasive communication, outnumber journalists by five to one. ${ }^{73}$ Consequently, the ability of journalists to counter-balance the influence of organised persuasive communication (»PR«) maybe be less today than it was in previous years. In short, then, power and its exercise is still at work, even in an apparently pluralised and complex media environment.

\section{Conclusions: directions for future research}

In matters of war and crisis, the history of media-state relations is one that is largely characterised by the dominance of the state and official sources coupled with a relatively high degree of compliance amongst media and journalists for the war aims of a government. Political communication scholarship, specifically the elite-driven orthodoxy, has explained such patterns through reference to multiple factors including reliance on official sources and ideological constraints. This is not, however, the complete picture, and a variety of neo-pluralist accounts have usefully explored important exceptions to the rule: such work does not overturn the elite-driven paradigm, but rather works with it in order to theorise in greater detail the more subtle variations and, importantly, try to understand exactly how and why media can sometimes come to play a more independent role in matters of war and crisis. Recent debates have revolved around a series of claims regarding the pluralising and diffusing consequences of the new media environment, some of which emphasise the irrelevance of existing political communication scholarship. Such claims, it is argued here, fail to take into account the extent to which traditional news media continue to dominate even in the Internet environment, the continued reliance of journalists upon official sources and the persistence of ideological imperatives. Most importantly, all scholarship on these issues has failed thus far to examine fully the extent and penetration of organised persuasive communication. With these points in mind, where should the focus of political communication research be directed?

First, a much more focused and analytically rigorous grasp of the consequences of the contemporary media environment for both journalism and public understanding of conflict needs to be developed. Overarching claims regarding empowerment, pluralisation and diffusion need to be replaced by more empirically and theoretically grounded analysis of how Internet-based communication is influencing existing media structures and journalism and how political actors, from elite to non-elite groups, fare under these circumstances. There is a significant stock, as discussed in this chapter, of neo-pluralist theorising which is particularly suited to developing and understanding how new communication technology might alter, although not transform, existing patterns of mediastate relations described by the elite-driven orthodoxy. These approaches should be exploited and developed further by academics in order to gain a better understanding of what is going on today.

73 http://www.pewresearch.org/fact-tank/2014/08/11/the-growing-pay-gap-between-journalis $\mathrm{m}$-and-public-relations/ (Download date 28 August 2014).

ZfP 61. Jg. 4/2014 
Second, greater attention needs to be paid to the very real possibility that patterns of wartime media-state relations have actually witnessed a decline in the quality of media and public understanding of conflict. Amongst all the academic and popular hyperbole regarding the "new media ecology «, there is a danger that some academics have simply failed to consider the possibility that the contemporary media environment actually works against greater levels of transparency and understanding. Declining budgets for journalism, noted above, a somewhat fragmented and diversified audience for conflict news, as well as continued and indeed strengthened approaches to organised persuasive communication, may well mean that state and elite influence over public understanding of war is stronger than in previous eras. This possibility needs to be taken seriously, rather than assumed out of the equation due to spurious assumptions regarding the inherent pluralism and inevitable transparency of the contemporary media environment.

This leads to a final point regarding organised persuasive communication. As noted at the start of this chapter, the importance of media in the context of winning war has always been understood, right back to the propaganda of the Second World War and before. Although poorly understood by much of the political communication literature on media and war, these approaches to influence and control remain a key priority for states, especially in the context of war and crisis. Few now dispute that people lived in an era of propaganda back in the early part of the $20^{\text {th }}$ century. The question that needs to be addressed is whether we still do; or, in other words, the extent to which the information environment continues to be significantly shaped by intentional strategies of organised persuasive communication aimed at influencing opinion. In research terms, this requires researchers to focus upon the institutional and organisational structures within governments and large organisations that create organised persuasive communication campaigns, the ways in which both deception and coercion can be key components of such campaigns, and the extent to which these campaigns shape media and public understandings.

The last 14 years of the post Cold-War/ post-9/11 international environment has been witness to two major Western-led wars in Iraq and Afghanistan, both of which are widely perceived now to have been strategic blunders, as well as emerging military engagement in crises in Iraq, Syria and the Ukraine, to name but a few: The need for informed public debate and democratic input to foreign policy decision making is as important as ever. This means developing more nuanced understandings of media-state dynamics and, most importantly, getting to grips with organised persuasive communication and the extent to which it might be distorting the public sphere.

\section{Summary}

This article provides an overview and critical assessment of the ways in which political communication scholarship has sought to understand and explain the importance of news media vis-à-vis war and international politics. It reviews existing approaches that have shaped debates over the last 30 years and critically evaluates the significance of new 
communication technologies and organised persuasive communication in this context. The central objective is to assess both the extent to which the orthodox elite-driven paradigm remains relevant to the 21st century and the major questions now facing attempts to theorise the relationship between war and media. It is argued that existing theoretical accounts retain significant purchase, despite the emergence of the Internetbased contemporary media environment, and that greater academic attention needs to be paid to organised persuasive communication.

\section{Zusammenfassung}

Der Beitrag gibt einen Überblick über den Stand und die Herausforderungen der politikund kommunikationswissenschaftlichen Forschung zur Rolle von Medien in militärischen Konflikten und internationaler Politik. Dazu werden zunächst kritisch die zentralen Ansätze diskutiert, die die wissenschaftliche Debatte in den vergangenen 30 Jahren bestimmt haben. Zudem wird auf neuere Ansätze eingegangen, die sich insbesondere mit der Bedeutung neuer Informations- und Komunikationstechnologien sowie Maßnahmen der organisierten persuasiven Kommunikation beschäftigen. Zentrales Ziel des Beitrags ist es herauszuarbeiten, inwieweit das traditionelle Eliten-zentrierte Paradigma auch im 21. Jahrhundert noch Gültigkeit beanspruchen kann und welches derzeit die zentralen Fragen sind, die sich im Hinblick auf die Rolle von Medien in militärischen Konflikten stellen. Dabei wird argumentiert, dass viele der bestehenden theoretischen Vorstellungen auch in Zeiten des Internet nach wie vor Gültigkeit beanspruchen können, dass die Forschung sich aber den Maßnahmen der organisierten persuasiven Kommunikation intensiver widmen sollte.

Piers Robinson, Medienmacht und Strategien der Kontrolle: $\mathrm{Zu}$ einer Theorie des Verhältnisses von Nachrichtenmedien und Krieg im 21. Jahrhundert 